\title{
Public Policies in the Field of Advanced Materials International Tendencies and Subsidies to the National Policy for Advanced Materials in Brazil
}

\author{
Felipe Silva Bellucci ${ }^{1}$, Maria Carlota Souza Paula ${ }^{2}$ \\ ${ }^{1}$ University of Brasília (UnB) and Brazilian National School of Public Administration (ENAP), Brazil \\ ${ }^{2}$ Brazilian National School of Public Administration, Brazil
}

KEY WORDS

Public Policies

Science, Technology, and Innovation

Advanced Materials

International Trends

\begin{abstract}
Currently, advanced materials are a source of interest for the private sector, since they are regarded as the foundation for the promotion of technology-based innovation and, also, because they have the potential to add value and competitive differential. Considering the efforts of the Brazilian Ministry of Science, Technology, Innovations, and Communications (MCTIC), which has established advanced materials as a priority, this work presents an analysis of the most important international public policies in the field of advanced materials, thus identifying their main characteristics, tendencies, and priorities, with the intent of subsidizing the devising of a National Plan for Advanced Materials in Brazil.
\end{abstract}

Received: $12 / 09 / 2020$

Accepted: 05/01/2020 


\section{Introduction}

I $\mathrm{n}$ Brazil, the promotion and incentive applied to the development of science, technology, and innovation are pivotal premises contemplated in article no. 218 of the Federal Constitution of Brazil. In this context, advanced materials can be considered one of the main enabling areas with great innovative potential. This area's development is historically associated with the evolution of mankind, deriving from it the names of historical periods, such as the stone and metal age, with breakthroughs, particularly in agriculture and war, for the population that dominated the transformation of these materials.

Today, advanced materials continue to arouse the interest of the academic world and the private sector. They are considered the basis for the promotion of technology-based innovation, due to the potential for adding value and competitive differential. Taking into account the efforts of the Ministry of Science, Technology, Innovation, and Communications (MCTIC) for the national scientific development, and the validity of the National Strategy for Science, Technology, and Innovation (ENCTI 2016-2022) (MCTIC, 2017), which establishes as a priority the Convergent and Enabling Technologies, which includes advanced materials.

Taking this context into account, a research project was developed at the National School of Public Administration (ENAP), in the scope of the program "Specialization in Management of Science, Technology and Innovation Policies" (ENAP, 2020), adding elements of training and professionalization of management in the area of S, T\&I, and stimulating the search for key elements, national and international trends, and priorities in the field of Advanced Materials to subsidize a Brazilian Public Policy for Advanced Materials.

This work presents an analysis of public policies and prospective studies in the area of advanced materials, to identify the main characteristics or structuring axes of such policies; identify trends in the area of advanced materials and present subsidies, in particular themes and priority actions for the development of a National Program of Advanced Materials.
The countries/blocks selected for analysis were the European Union, BRICS, United States, Japan, and Germany, due to the increased investment in R\&D and the relevance of the area of Advanced Materials as a technology capable of driving innovation and economic development.

\section{Methodology}

For the development of this study, an analysis of public policies and prospective studies in the area of advanced materials were carried out to identify the main characteristics or structuring axes of these policies; identify trends in the area of advanced materials and present subsidies, in particular themes and priority actions for the development of a National Program of Advanced Materials. The countries/blocks selected for analysis were the European Union, BRICS, United States, Japan, and Germany, due to the increased investment in R\&D and the relevance of the area of Advanced Materials as a technology capable of driving innovation and economic development.

\section{Strategic Relevance of the Area}

Considering its transversal reach, the area of advanced materials is historically associated with the fields of chemistry and physics of materials, materials engineering, and others. The importance of this area for the economy and technological development is unanimous, as it has improved the performance of materials, reduced costs, increased component life, and provided more sustainable disposal at the end of the product cycle, among other advances.

\subsection{Advanced Materials Concept}

Corroborating the ENCTI 2016-2022, "Advanced Materials" are "materials and their associated technological process, with the potential to be exploited in high added-value products and applications". It is a multidisciplinary theme (for instance, involving the fields of physics, chemistry, and applied mathematics), transversal (encompassing technological areas such as electronics, photonics, and biosciences), and with a multi-sectoral market (covering the energy, transportation, health care, and packaging markets). 


\subsection{Innovative Potential of Advanced Materials}

It is important to note that advanced materials (new materials, functional materials, synthetic materials, and the like) are some of the most direct forms of adding value to already established technologies. The use of these materials, or the improvement of processes to obtain traditional materials, manage to reduce costs, improve physical and chemical properties (for example greater resistance to thermal degradation, abrasion, and aging, reduction in density, increase in electrical conductivity, among others), add new functionalities (multifunctional materials), generate more environmentally sustainable processes, provide new purposes to waste and several other direct applications (CGEE, 2010).

\subsection{Economic Potential of Advanced Materials}

The business and industrial sectors focus on the development and use of Advanced Materials to put better products on the market, keeping the investment/return ratio as favorable as possible. Private investment in new technologies, including advanced materials, has as its main objective the creation and maintenance of competitive advantages, including: (i) reduced costs and increased profitability; (ii) sustainability and environmental impact; (iii) increased customer satisfaction and loyalty; (iv) regulatory compliance; (v) competitiveness and market differential; among others.

\subsection{Academic Importance of the Theme}

The area of Advanced Materials is mainly conducted by professionals with training in material sciences, engineering, mathematics, physics, and chemistry. Currently, Brazil, in the area of materials and related fields, offers 66 graduate courses recognized by the Ministry of Education (MEC) (MEC, 2020) and 36 postgraduate courses in the area of materials (Master's and Ph.D.), recognized and evaluated by the Coordination for the Improvement of Higher Education Personnel (CAPES) (CAPES, 2020). On average, there are about 7000 graduate and 500 postgraduate vacancies. From a global perspective, there is a significant increase in scientific research in the area of Advanced Materials, which is reflected in a growth of approximately $140 \%$ in scientific production between 2004 and 2014 (BLAND, 2014). In Brazil, there is already a relatively established community, responsible for the production of more than 5000 articles/documents indexed in the triennium 2016-2018, according to the SJR Portal (PORTAL SJR, 2018). This production corresponds to approximately $2.5 \%$ of world production in the area. This puts the Brazilian community in a position of relative prominence in the world context.

\subsection{Materials Research Groups}

Regarding the Brazilian groups dedicated to research in "Materials", 530 research groups were found in the Directory of Research Groups of the National Council for Scientific and Technological Development (CNPq) (PORTAL CNPq, 2020), which presented the term "Materials" next to the group name. Considering a universe of 37.640 research groups in the 2019 directory, the 530 research groups associated with the materials represented $1.4 \%$ and approximately 2,809 researchers, as the average of researchers per research group was 5.3 researchers.

\section{Advanced Materials Programs in Brazil}

Historically, the Brazilian government, particularly through the MCTIC and its development agencies, and the State Research Support Foundations (FAPs), has boosted structured programs for the development of the national S, T\&I. Therefore, the four main newest national research, technological development, and innovation programs, which cover several areas, including Advanced Materials, are National Institutes for Science and Technology (INCT); Research, Innovation and Dissemination Centers (CEPID) of the São Paulo State Research Support Foundation (FAPESP); National System of Nanotechnology Laboratories (SisNANO); and the Brazilian Company of Research and 
Industrial Innovation (Embrapii). Below is the main information about the programs.

INCT (INCT, 2020; CONFAP, 2016): The INCT Program was officially launched on November 27,2008 , by the MCTIC, via CNPq, with ambitious and comprehensive goals, associated with the possibility of mobilizing and articulating the best research groups in areas related to scientific breakthroughs and strategic areas for the country's sustainable development; boosting basic and fundamental scientific research in the international context, in a competitive way; stimulating the development of cutting-edge scientific and technological research, associated with applications to promote innovation and entrepreneurship, in a close effort with innovative companies. From the standpoint of support provided to INCTs, the MCTIC made three public calls, via CNPq, in 2008, 2010, and 2014 , for R\$ 1.1 billion, including resources from the MCTIC (FNDCT), CNPq and FINEP, CAPES and some State Foundations for Research Support, such as FAPESP, FAPERJ, and FAPEMIG. In Advanced Materials, based on the lines of research and technological development, among the 122 INCTs contracted in 2008, eight INCTs were identified $(7 \%$ of the total INCTs, or $25 \%$ of the total INCTs in related areas) with actions that directly or indirectly involve the area of advanced materials.

CEPID (CEPID, 2020): The CEPID program was conceived by the FAPESP in 2000, with the support of 11 research centers from 2001 to 2013. In 2011, a second call for proposals was announced, which originated the 17 CEPIDs currently supported. The program aims to develop basic or applied research, focused on specific themes; contribute to innovation through technology transfer; and provide extension activities focused on primary and secondary education, and also for the general public. The most relevant profile of the Centers is the multiplicity of their activities. The Centers are responsible for the development of fundamental or applied research at a high level, but also the search for technology-based innovation opportunities, entrepreneurship, knowledge transfer to the private sector and society. The total financing for the 17 Centers is estimated at about $\mathrm{R} \$ 1.4$ billion. $\mathrm{R} \$ 760$ million from the FAPESP and R $\$ 640$ million in salaries paid by the host institutions to researchers and technicians over 11 years. Regarding the Advanced Materials subject, based on the lines of research and technological development, four CEPIDs were identified $(24 \%$ of the total CEPIDs), with actions that directly and indirectly involve this area.

SISNANO (SISNANO, 2020): One of the key actions of the Brazilian Nanotechnology Initiative (IBN), the SisNANO was established by Ordinance No. 245 of April 5, 2012, which consists of a system of laboratories focused on research, development, and innovation (RD\&I) in nanosciences and nanotechnology. The pivotal feature is the multi-user character and open access, through the presentation of project proposals in PD\&I, or the request for services. The SisNANO is responsible for the General Coordination for Development and Innovation in Strategic Technologies (CGTE), the Secretariat of Entrepreneurship and Innovation (SEMPI), the Ministry of Science, Technology, Innovation and Communications (MCTIC). The first stage of the System (2013-2018) had two categories of laboratories: the Strategic (08 laboratories) directly associated with the Federal Government and the Associates (16 laboratories). Since the beginning of the Program in 2013, the laboratories have received approximately $\mathrm{R} \$ 88$ million in resources from the MCTIC/FNDCT. The main objective of these resources was to improve the laboratory infrastructure, the maintenance of the technical-scientific staff qualified to develop the missions of the laboratories, and enable open access to the laboratories, serving users and institutions in the public and private sectors.

EMBRAPII (EMBRAPII, 2020): Embrapii is one of the research institutes of the MCTIC, qualified by the federal government as a social organization. The mission is to support technological research institutions, in specific areas of skill, to carry out technological research development projects for innovation, in cooperation with companies in the industrial sector. The focus is on business demands and the target is risk-sharing in the pre-competitive phase of innovation. In the area of Advanced Materials, Embrapii currently has the following 
accredited-Embrapii Units: Technological Research Institute (IPT) in high-performance materials, SENAI Institute of innovation in metallurgy and special alloys, National Center for Research in Energy and Materials (CNPEM) in biomass processing, SENAI Institute of Innovation in Polymer Engineering and others.

Figure 1 is an organization chart that presents four of the main national programs dedicated to the development of science, technology, and innovation in Brazil, interfaced with the area of Advanced Materials.

Figure 1. Organization chart with the main Brazilian programs for Advanced Materials and their respective focuses.

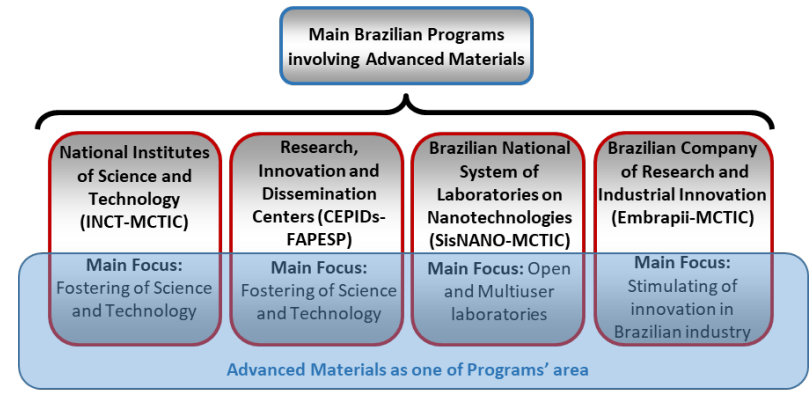

Source: Own author, 2020.

\section{International Programs for Advanced Materials}

Advanced Materials are strategic and a priority for most societies whose economy is knowledge-defined. Below is an analysis of the key strategies adopted by the European Union, BRICS, the United States, Germany, and Japan in Advanced Materials.

\subsection{European Union}

Generally speaking, the theme of science and technology, with specific plans for the field of converging and enabling technologies, where advanced materials are included, remains a priority axis in European economic development. It is also its main instrument in the "Horizon 2020" framework program. It has three main strategic axes (Excellence Research, Industrial Leadership, and Social Challenges). In the Work Programmes (2014-2016, 2016-2018, and 20182020), the theme Advanced Materials has had a greater presence in the axes of Industrial Leadership and Excellence Research, associated with enabling technologies (Key Enabling Technologies - KETs). KETs, like advanced materials, photonics, nanotechnology, and biotechnology, are at the core of innovative products. For instance, smartphones, energy storage systems, lighter structures, nanomedicines, intelligent fabrics and others (Comissão Europeia, 2014, H2020 FET, 2017).

\subsection{BRICS}

BRICS, an acronym associated with the founding member countries - Brazil, Russia, India, and China - are a political group for cooperation in different sectors of society. The main actions of BRICS are focused on two strands: coordination in international meetings and organizations, and the construction of an agenda of multisectoral cooperation among members, particularly with regard to economic and scientific interests. In 2015, a Memorandum of Understanding for cooperation was signed, where three axes of governance and decision-making were established: meeting of Ministers of ST\&I; the meeting of Senior Officers on ST\&I; and Working Groups on ST\&I. Regarding Advanced Materials, four actions involving this area were identified: BRICS Center for Materials Sciences and Nanotechnology; BRICS Working Group on Research Infrastructures and Mega Science Projects; BRICS Forum for Young Scientists; and BRICS Development Agencies - Joint Multilateral Call (BRAZIL BRICS, 2017).

\subsection{United States}

The U.S. innovation system strongly values investment in science, technology, and innovation, made primarily by the government through its mission-oriented agencies, but also with strong private sector influence. One of the most interesting points in the materials area in the United States is the attention to the interface between the materials area and advanced industry. The country has established several public policies to revitalize and increase the competitiveness of American industry. From the American standpoint, the area of advanced materials plays an important role in the advanced industry, since the goal is to achieve multifunctionality of materials, increasing the useful 
life of machinery, developing reference materials, reducing costs, and increasing physical performance. As such, the field of materials has been identified as one of the pillars of the National Plan for Advanced Industry, together with technological platforms for production, advanced industrial processes, and data and development infrastructure (Strategic Plan, 2012).

\subsection{Germany}

Science, technology, and innovation are the main pillars of the German economy, which restructured the country after the Second World War. They are characterized by multidisciplinary and high-tech infrastructures, with a social and entrepreneurial culture aligned with innovation. In advanced materials, the domain is mostly settled by the following institutions: Fraunhofer Association; German Federation of Industrial Research Associations; and Max Plank Association. From the point of view of strategic planning for the materials area, the German Federal Ministry of Education and Research launched its main materials innovation program in 2004, known as Materials Innovation for Industry and Society (WING). The central aim of the program is to increase innovation in the field of materials for industry through missionoriented research, while, at the same time, leveraging the use of materials to overcome social, economic, and the "major German challenges" - mobility, infrastructure, health and the environment (Federal Ministry, 2019).

\subsection{Japan}

Japan is one of the world's great examples of how a country with a small geographical size, few natural resources, and great weather vulnerability can, through science, technology, and innovation, be one of the world's great economic and wealth-generating peaks. A major part of Japanese knowledge production in the field of materials is conducted by universities. There are three other institutions with an important role in Japanese technological development in materials: the National Institute of Advanced Science and Technology, the Japanese Agency of Science and Technology, and the National Institute of Materials Sciences.
Japan's 5th Basic Science and Technology Plan (2016-2020), which is equivalent to our National Science and Technology Strategy, has chosen Nanotechnology and Advanced Materials as one of its four priority areas, along with the analysis of large sets of stored data (big data), biotechnology and artificial intelligence. As in Brazil, in Japan, the areas of nanotechnology and materials are considered to have a close epistemological relationship, with a special economic-technological dimension, when associated with manufacturing and information and communication technologies.

As an example, Figure 2 shows the organizational charts that represent the support system for the area of advanced materials in the United States (a) and Germany (b). The remaining organizational charts can be seen in (Bellucci, 2019).

Figure 2. Organization chart representing the support system to the field of advanced materials in the United States (a) and Germany (b).

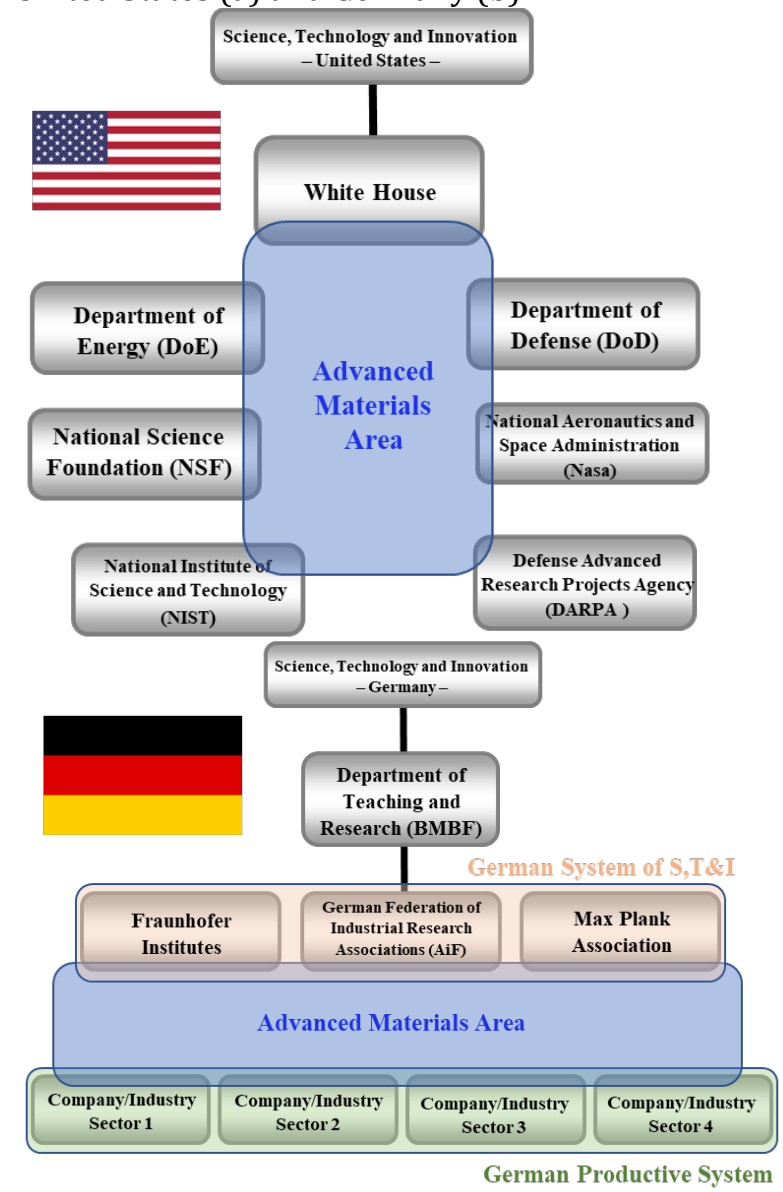

Source: Adapted from Bellucci, 2019. 


\section{Main Characteristics and Trends Identified}

Based on the main documents related to the topic of Advanced Materials, and on the history of promoting S,T\&I in each country/group of countries, below is a summary of the main characteristics and trends of each analyzed international program.

European Union: (i) Strong international cooperation with the intent to promote scientific and technological development; (ii) Encouraging the internationalization of research projects and human resources training, with international teams, and strong exchange of researchers; (iii) No prioritization of classes or applications for advanced materials; and (iv) Encouraging the strengthening and involvement of micro and small technology-based companies.

BRICS: (i) Strong international cooperation to promote scientific and technological development and human resource training; (ii) nanomaterials, materials for energy, magnetic materials, and materials for biotechnology and health as priority areas; and (iii) fostering unique research infrastructures and their sharing.

United States: (i) Decentralization of the U.S. strategy for advanced materials through agencies, departments, and foundations of the U.S. strategy for advanced materials; (ii) taking into consideration the percentage invested by the country in S, T\&I, the fields of defense, health, energy, nanomaterials, and advanced industry were regarded as a priority; (iii) the identification of materials as one of the pillars of the national industry's rehaul, and (vi) the implementation of a national action to use computational tools to accelerate the materials' development.

Germany: (i) Excellence of national institutions associated with the scientific and technological development of advanced materials; (ii) industrial orientation mostly geared towards the development of industry and attention to small and medium-sized technologybased enterprises; and (iii) emphasis on the development of new materials using simulation and modeling computational tools.

Japan: (i) research and development activities of advanced materials conducted mainly by public research institutions, especially universities; (ii) public research oriented towards the demands and needs of the productive sector; (iii) fields of convergent technologies as priorities, especially the convergence between nanotechnology, advanced materials, and advanced manufacturing; (iv) a high degree of strategic coordination by federal agencies, associated with routine international prospecting activities; and (v) emphasis on the development of new materials using computational tools for simulation and modeling.

Table 1 lists the main characteristics and trends identified in public international science, technology, and innovation programs and documents in the area of advanced materials from the countries studied. 
Table 1.

List of main characteristics and trends identified in international public S, T\&I programs, and documents in the field of advanced materials.

\begin{tabular}{|c|c|c|c|c|c|c|}
\hline $\begin{array}{c}\text { Country/Group } \\
\text { of countries }\end{array}$ & $\begin{array}{l}\text { International } \\
\text { Cooperation }\end{array}$ & $\begin{array}{l}\text { Training of } \\
\text { Human } \\
\text { Resources }\end{array}$ & $\begin{array}{l}\text { Supporting } \\
\text { the Private } \\
\text { Sector }\end{array}$ & $\begin{array}{l}\text { Financing fo } \\
\text { the S\&T }\end{array}$ & Priority Areas & $\begin{array}{c}\text { Other } \\
\text { features }\end{array}$ \\
\hline $\begin{array}{l}\text { European } \\
\text { Union }\end{array}$ & $\begin{array}{l}\text { - Strong } \\
\text { international } \\
\text { cooperation for } \\
\text { the } \\
\text { development of } \\
\text { S\&T in the EU. }\end{array}$ & $\begin{array}{l}\text { - Encouraging } \\
\text { the training } \\
\text { of specialized } \\
\text { human } \\
\text { resources. }\end{array}$ & $\begin{array}{l}\text { - Stimulating } \\
\text { micro and } \\
\text { small } \\
\text { technology- } \\
\text { based } \\
\text { companies. }\end{array}$ & $\begin{array}{l}\text { - Support for } \\
\text { major } \\
\text { European } \\
\text { projects. }\end{array}$ & $\begin{array}{l}\text { - Not } \\
\text { prioritizing } \\
\text { classes or } \\
\text { applications for } \\
\text { advanced } \\
\text { materials. }\end{array}$ & $\begin{array}{l}\text { - Promotion } \\
\text { of pilot plants } \\
\text { for tests and } \\
\text { scaling up. }\end{array}$ \\
\hline BRICS & $\begin{array}{l}\text { - Strong } \\
\text { international } \\
\text { cooperation to } \\
\text { promote S\&T. }\end{array}$ & - & - & $\begin{array}{l}\text { - Strong } \\
\text { incentive to } \\
\text { joint S\&T } \\
\text { Multilateral } \\
\text { Calls, including } \\
\text { for Advanced } \\
\text { Materials }\end{array}$ & $\begin{array}{l}\text { Nanomaterials, } \\
\text { materials for } \\
\text { energy, } \\
\text { materials for } \\
\text { biotechnology, } \\
\text { and health. }\end{array}$ & $\begin{array}{l}\text { - Promotion } \\
\text { of singular } \\
\text { research } \\
\text { infrastructure } \\
\text { s. }\end{array}$ \\
\hline United States & - & - & $\begin{array}{l}\text { - Materials as } \\
\text { a pillar for } \\
\text { the } \\
\text { revitalization } \\
\text { of the } \\
\text { national } \\
\text { industry. }\end{array}$ & $\begin{array}{l}\text { - Promotion of } \\
\text { R\&D in } \\
\text { advanced } \\
\text { materials, via } \\
\text { national } \\
\text { agencies (NASA } \\
\text { and DOE). }\end{array}$ & $\begin{array}{l}\text { - Defense, } \\
\text { health, energy, } \\
\text { nanomaterials, } \\
\text { and advanced } \\
\text { industry. }\end{array}$ & $\begin{array}{l}\text { - Effort to join } \\
\text { materials and } \\
\text { computationa } \\
\text { l tools to } \\
\text { accelerate } \\
\text { R\&D. }\end{array}$ \\
\hline Germany & - & - & $\begin{array}{l}\text { - Materials } \\
\text { developed } \\
\text { according to } \\
\text { industrial } \\
\text { needs. }\end{array}$ & $\begin{array}{l}\text { - Investment in } \\
\text { oriented by a } \\
\text { mission and } \\
\text { looking for } \\
\text { excellence in } \\
\text { research. }\end{array}$ & - & $\begin{array}{l}\text { - Strong use } \\
\text { of } \\
\text { computationa } \\
\text { l tools for } \\
\text { R\&D. }\end{array}$ \\
\hline Japan & - & - & $\begin{array}{l}- \text { - R\&D } \\
\text { activities } \\
\text { driven by } \\
\text { demands } \\
\text { from the } \\
\text { private and } \\
\text { industrial } \\
\text { sectors. }\end{array}$ & $\begin{array}{l}\text { - Promotion of } \\
\text { public research } \\
\text { institutions, } \\
\text { especially } \\
\text { universities. }\end{array}$ & $\begin{array}{l}\text { - Convergence } \\
\text { between } \\
\text { nanotechnolog } \\
\text { y, advanced } \\
\text { materials, and } \\
\text { manufacturing. }\end{array}$ & $\begin{array}{l}\text { - Using digital } \\
\text { technologies } \\
\text { in the R\&D of } \\
\text { new } \\
\text { materials. }\end{array}$ \\
\hline
\end{tabular}

Source: Adapted from Bellucci, 2019.

\section{Elements of Design Thinking when Discussing the Results}

To confirm with the stakeholders (target audience) the main characteristics to be suggested for the elaboration of a National Plan for Advanced Materials for Brazil, the following intervention strategies were outlined, based on the Design Thinking methodology (BROWN, 2017): (i) interviews with strategic partners; and (ii) prototyping and ideation using digital tools.

\subsection{Interviews with Experts}

To gather a more detailed perception of the needs of end-users in the field of advanced materials, a cycle of interviews was conducted with experts in the field, considering the three branches of the triple helix (academy, government, and business). During the interview cycle, the most relevant findings are associated with: (i) the limited knowledge of the production chain and product life cycle; (ii) the training of 
human resources at undergraduate and graduate levels with few market-related technical skills; (iii) technology-based ventures whose main market is only domestic; (iv) identification of disruptive and future-bearing fields that need to be fostered by the State; (v) Innovation Centers with low capacity to support and instruct public and private partners in the development of the partnership; and others.

\subsection{Prototyping and Ideation with Digital Tools}

With the intention to (i) present and discuss the main concepts and strategies associated with the elaboration of the National Plan; (ii) to hastily disseminate and simplify the understanding of the main concepts of the National Plan; and (iii) to disseminate the actions, programs, projects and initiatives conceived for the field of advanced materials, the following were internally prototyped, not institutionally by the MCTIC, a web page 1, an application, based on the web page and graphic animation2, all using free tools available for the community. The main learning associated with prototyping was the possibility of synthesizing the initial structure of the National Plan and simplifying the understanding of the Plan by the main stakeholders.

\subsection{Main Trends, Characteristics, and Identified Opportunities}

Based on the analysis of the main national and international trends in the field of Advanced Materials, the results of the interviews and ideation actions, their adherence to the national context and Brazil's current opportunities and challenges (Bellucci, 2019), the main suggestions for the subject are presented below.

- Interaction between the Academy and the Private Sector: Considering the challenging scenario of the national macroeconomics, and also taking into account that the field of Advanced Materials is cross-sectional and capable of

\footnotetext{
${ }^{1}$ Web page available at: https://fsbellucci.wixsite.com/material 2 Graphic Animation available at: https://videos.mysimpleshow.com/eQWLku7Fnn
}

adding value to national technologies, the national public actions in this field should generate a robust knowledge base and be aligned with the needs of the private sector, while favoring the emergence of innovative technology-based enterprises.

- Specialized Human Resources: Public actions in the field of advanced materials should collaborate to (i) increase the percentage of our society with college degrees, extending to the field of materials; (ii) encourage training and the creation of favorable conditions for technology-based entrepreneurship; and (iii) create a favorable environment for the inclusion of master degree and Ph.D. holders in techrelated national companies.

- Digital Technologies: Considering the quick and disruptive evolution of digital technologies in recent years (highperformance computing, big data, Internet of Things, machine learning, and others), its use should accelerate, reduce costs and risks associated with technological development in the field of advanced materials.

- International Cooperation: This is a strategic structuring axis for public actions in the field of advanced materials, with the potential to accelerate national technological development in fields of interest, promote the exchange and internationalization of knowledge and innovative practices.

- Fields for the Future: Considering the subject matters identified in the international national plans for advanced materials, the main fields are (i) aerospace and defense; (ii) energy; (iii) health and biotechnology; and (iv) nanotechnology and nanomaterials. It should be emphasized that there are opportunities in emerging fields, such as metamaterials, high-entropy materials, multifunctional materials, materials with self-renewal capacity, materials for targeted diagnosis and therapy, carbon derivatives (graphene, fullerenes, and carbon nanotubes), rare earth, among others. 
- National Biodiversity: Brazil is a continental-sized country, with singular biodiversity (flora, fauna, and biomes) in the world, encompassing $20 \%$ of the total number of species on Earth. National biodiversity is a great competitive advantage for the country, albeit barely explored, with unique potential for the discovery of new materials and their properties.

- Strategic Mineral Resources: A large share of Brazil's trade balance is associated with the export of raw materials of mineral origin with low added value, while also having a large part of the world's reserves of various strategic minerals. It is necessary to devise programs and policies to add value to exports of national mineral resources.

- Overcoming Social Issues in Brazil: Social issues such as poverty, low access to drinking water, malnutrition, limited access to health, inadequate basic sanitation, among others, are obstacles to be overcome in Brazil, and the State should provide basic public policies to do so. The field of advanced materials shows the potential to add value, reduce costs, and disseminate technological solutions to different social issues.

\section{Final Considerations}

When considering the strategic relevance of the field of advanced materials for the academic, social, and business sectors, an analysis of public policies and prospective studies in this field was conducted to identify the main national and international characteristics and trends in the field of advanced materials. As the main outcome of this study, the Brazilian Ministry of Science, Technology, Innovation and Communications (MCTIC) published in 2019 the S, T\&I Action Plan for Convergent and Enabling Technologies, volume III - Advanced Materials (MCTIC, 2019), based on 07 (seven) axes or strategic actions (institutionalization, information systematization), human resources and entrepreneurship, ICT-company interaction, international cooperation, digital technologies, and disruptive topics), for which guidelines have been proposed to be conducted in the programs and activities carried out by the key players of Brazil's National System of Science, Technology, and Innovation in the field of advanced materials.

\section{Acknowledgements}

The authors acknowledge the Foundation for Research Support of the Federal District Government (Fundação de Apoio à Pesquisa do Distrito Federal - FAPDF), TOA $n^{\circ} 256 / 2019$, for its financial support and the Ministry of Science, Technology, Innovation and Communication of Brazil for its supporting. 


\section{References}

Bellucci, Felipe S. (2019). Políticas públicas na área de materiais avançados, principais características $e$ tendências: sugestões à política de CT\&I brasileira. Brasília: ENAP.

Bland, S. (2014). Senior Publisher and Editor of Materials Today. Data derived from Scopus. Documento: Advanced Materials and Applications: Tackling New R\&D and Engineering Challenges. Elsevier.

Brazil. BRICS - Brasil, Rússia, Índia, China e África do Sul. Ministério das Relações Exteriores do Brasil. Disponível em: <http://www.itamaraty.gov.br/pt-BR/politica-externa/mecanismos-interregionais/3672-brics>. Acesso em: 24 abr. 2020.

Brazil. Ministério da Educação-MEC. Cadastro e-MEC de Instituições e Cursos de Educação Superior, base de dados oficial e única de informações relativas às Instituições de Educação Superior - IES e cursos de graduação do Sistema Federal de Ensino. Available at: <http://www.emec.mec.gov.br>. Accessed on: 02 jan. 2020.

Brazil. Ministério da Ciência, Tecnologia, Inovações e Comunicações. Estratégia Nacional de Ciência, Tecnologia e Inovação 2016-2022 (ENCTI). P. 131, 2017.

- (2019). Secretaria de Empreendedorismo e Inovação. Plano de ação de ciência, tecnologia e inovação para tecnologias convergentes e habilitadoras: materiais avançados. F. Silva Bellucci et al. (org.). Brasília: Ministério da Ciência, Tecnologia, Inovações e Comunicações, 4 v. (v .2; 52 p.): il.

- (2019). Secretaria de Empreendedorismo e Inovação. Plano de ação de ciência, tecnologia e inovação para tecnologias convergentes e habilitadoras: materiais avançados. F. Silva Bellucci et al. (org.). Brasília: Ministério da Ciência, Tecnologia, Inovações e Comunicações. 4 v. (v .2; 52 p.): il.

Brown, T. (2017). Design Thinking: Uma metodologia poderosa para decretar o fim das velhas ideias. Editora Alta Books.

Centro de Gestão e Estudos Estratégicos (CGEE), Ministério da Ciência, Tecnologia, Inovações e Comunicações (2010). Materiais avançados no Brasil 2010-2022. Brasília.

Conselho Nacional das Fundações Estaduais de Amparo à Pesquisa. Resultados e Impactos do Programa Institutos Nacionais de Ciência e Tecnologia. São Luiz, 2016. Available at: <http://confap.org.br/news/wp-content/uploads/2016/06/panorama-INCT-CONFAP-Maranhão1.pdf>. Accessed on: 02 jan. 2020.

Conselho Nacional de Desenvolvimento Científico e Tecnológico (cnpq). Diretório de Grupos de Pesquisa. Available at: <http://lattes.cnpq.br/web/dgp>. Accessed on: 02 jan. 2020.

Cordenação de Aperfeiçoamento de Pessoal de Nível Superior. Documento de Área: Materiais. Available at: <http://www.capes.gov.br/component/content/article/44-avaliacao/4676-materiais>. Accessed on: 02 jan. 2020.

Escola Nacional de Administração Pública. Programa de Especialização em Gestão de Políticas de Ciência, Tecnologia e Inovação. Available at: <https://suap.enap.gov.br/portal/curso/4/>. Accessed on: 02 jan. 2020.

European Commission (2012). Technology and market perspective for future Value Added Materials. Final Report from Oxford Research AS.

H2020 FET projects for technologies with new materials. Available at: <http://ec.europa.eu/programmes/horizon2020/en/news/h2020-fet-projects-technologies-newmaterials>. Accessed on: 02 Jan. 2020.

Institutos Nacionais de Ciência e Tecnologia. Available at: < http://inct.cnpq.br/>. Accessed on: 02 jan. 2020.

Office of the President National Science, E., \& Council, T. (2012). A National Strategic Plan for Advanced Manufacturing. Disponível em: <https://energy.gov/sites/prod/files/2013/11/f4/nstc_feb2012.pdf>. Acesso em: 24 abr. 2020.

Portal SJR. Scimago Journal and Country Rank. Available at: <https://www.scimagojr.com/>. Accessed on: 02 Jan. 2020. 
Programa Centros de Pesquisa, Inovação e Difusão (CEPID) da Fundação de Amparo à Pesquisa do Estado de São Paulo (FAPESP). Available at: <http://cepid.fapesp.br/home/>. Accessed on: 02 jan. 2020.

Research in Germany, Federal Ministry of Education and Research. Disponível em: <http://www.research-in-germany.org/en/research-funding.html>. Acesso em: 24 abr. 2020.

Sistema Nacional de Laboratórios em Nanotecnologias (sisnano), Ministério da Ciência, Tecnologia, Inovações e Comunicações. Available at: http://www.mctic.gov.br/mctic/opencms/tecnologia/incentivo_desenvolvimento/sisnano/sisnan o.html. Accessed on: 02 jan. 2020. 